\title{
Marzo es marzo es marzo es marzo
}

\author{
María Ángeles Pérez López \\ Universidad de Salamanca
}

Escribía Gertrude Stein un conjunto de textos en los que se desnuda la apariencia de los significados. Y digo bien, apariencia de los significados, porque el lenguaje es siempre un modo de acceso a lo real (sea lo que sea lo real, sea lo que sea el lenguaje) que no logra entrar en la médula misma de vivir. De ahí que una y otra vez, cada generación se vea impelida a escribirse, a preguntarse, a decirse (y desdecirse) ante la imposibilidad de agotar el terreno de sombras en el que caminamos.

Pero, ¿qué palabras brotan en el mismo ojo del huracán, en el derrumbe estrepitoso de cualquier apariencia? La pandemia global nos ha colocado justamente ahí, en un lugar sin certeza ni asideros, sin la convicción (más o menos estable) de que podemos acceder a ciertas formas de lenguaje sobre lo vivido. En relación con ello, estos meses me están resultando particularmente sombríos. Hubiera querido escribir "me han resultado" pero no hay modo de utilizar el pasado (no hoy, 2 de septiembre de 2020, a las 2 horas y 20 minutos del día), ni si quiera aunque el sol y las noticias quieran desmentirnos.

Como personas entregadas al estudio de los libros, el encierro no tenía por qué resultarnos ajeno. Eso creían mis vecinos, mi familia, eso creía yo misma. Pero no es así. Descubrí una verdad latente a la que no había debido enfrentarme aún: un libro jamás es una experiencia de confinamiento porque aunque trace una atmósfera irrespirable, aunque su exigencia verbal sea inmensa, está atravesado por múltiples imaginarios, o en diálogo con múltiples imaginarios que derivan de la propia experiencia de lectura, lo que multiplica sus posibilidades hacia todos los afueras y lo lanza a alguna clase de pasado y de futuro. ¿Cómo enfrentar la experiencia de confinamiento vivida desde el 14 de marzo —esa catástrofe sin lenguaje que la dijese- ante un horizonte que se vino abajo y una emergencia sanitaria que sigue golpeando de modo severo, incluso si no olvidamos que la humanidad se ha enfrentado recurrentemente a toda clase de dificultades? En ese momento no hubo imaginario posible: solo la recurrente consulta de mapas o datos, y la angustiada repetición, a modo de mantra, de fórmulas consabidas (pandemia, peste, pesar).

Pronto, sin embargo, empezó a aflorar la creatividad como disparador, se trazaron vínculos cercanos y lejanos, y surgió la propuesta de múltiples foros y espacios de reflexión conjunta que también se apoyaron en la (re)lectura de los libros que 
se habían acercado a la pandemia, la peste y el pesar (ratificando aquello de que lo vulnerable es la condición misma de la experiencia humana, aunque no fuéramos tan conscientes de ello como hasta el momento en que marzo estalla con su corolario larguísimo de días sin día).

El reto fue inmediato: tras el shock inicial, tras la conmoción y la afasia, hacer frente a la docencia (síncrona o asíncrona, en streaming, grabada o de ambas maneras o de todas aquellas maneras que supimos imaginar) y al deseo de ser soporte, de trazar una red (múltiples redes) que sostuvieran a mis estudiantes ante una incertidumbre que nos mordía los tobillos por igual. Todos los lenguajes revelaron su enorme vulnerabilidad: el de la salud como una certeza, el del desarrollo y la formación como certezas, el de la palabra futuro como una certeza. Instalándonos en lo precario, fuimos atendiendo docencia, evaluación, investigación... Los libros nos han sostenido (me han sostenido). Sin embargo, gran parte del trabajo habitual se mostró totalmente prescindible, aunque las autoridades académicas insistieran en protocolos sustituidos permanentemente. Lo único que me resultó absolutamente permanente fue la necesidad de no perder esa red debilitada de contacto con mis estudiantes, con quienes hacían sus trabajos de investigación, con quienes tenían que defender sus propuestas de fin de grado o máster... Solo me resultaron imprescindibles esos lenguajes precarizados en su capacidad de cercanía. Y siempre la poesía como un abismo compartido y sin red, precisamente porque la poesía no teme desvelar la apariencia de los significados, no se teme a sí misma. Pensé tanto en Stein porque a falta de Rose is a rose is a rose is a rose ("Sacred Emily") a mí solo me quedaba marzo ("Sacred Life"):

\section{"Marzo"}

Vivimos en palabras que van desplomándose según las nombramos.

Dijimos marzo y entonces, de las cinco preciosas y precarias letras caía la o como un espacio insufrible, el recuento inequívoco de grano o fruto o cuerpo bajando hasta su muerte.

La o en que cada brazo se sostuvo. La que se agitaba, inquieta, cuando mueves el pelo.

La que se mide en grados, como mides la combustión del tiempo en el amor.

La o de los respiradores que convocan el oxígeno con violencia y luego te entregan la palabra salud junto al sudor metálico del miedo.

La que se ahoga en los cuidados críticos, los protocolos del hospital, el monólogo inaudible de la noche en goteros que silban por su asfixia. 
La que conoce el flujo de la sangre cuando no puede salir a manchar las mañanas.

La que sabe que afuera está la flor con su aroma nervioso y primordial.

La que nombró el dolor, el box, los resucitadores.

La de quien enfermó y está solo en su alfabeto, el nicho, la turbulenta almohada de la fiebre.

La del invierno que no termina de marcharse y encharca tu corazón con su tristísimo conteo de hemogramas.

Entonces tomas el resto de letras. Si zozobra marzo roto frente a ti, te aferrarás a las maderas del naufragio, el caudalímetro que cuenta la esperanza. Plantarás sobre abril todos los muertos. Ya no podrá ser nunca el mes más cruel. Desde su nombre clamaremos mayo y traerá un largo lienzo transparente en que amanezca el día y su certeza.

En el pájaro, la o estará cantando.

Que llegue el sol, su círculo perfecto, su abrazo irrevocable y sorprendido.

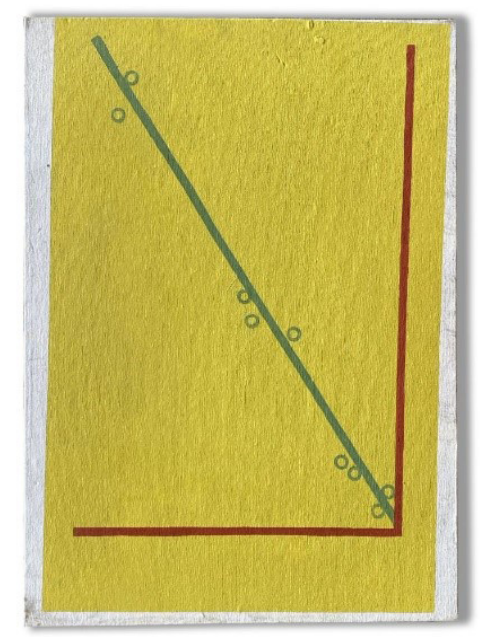

Poema de María Ángeles Pérez López, ilustración de Rodrigo Pimenta

Revista POY Latam, "Postales del Coronavirus", junio de 2020 